\title{
Heat gains utilisation and system efficiency influence to the heat demand of a building heating
}

\author{
Kęstutis Valančius, Vilūnè Lapinskienè \\ Vilnius Gediminas Technical University, Saulètekio al. 11, 10223 Vilnius, Lithuania
}

\begin{abstract}
Experience shows that often theoretical heat demand and real building heat use varies, and in some cases a significant percentage. This can be explained by the fact that the identification methods of rooms' heat demand are inaccurate or incorrect use. One issue for discussion is the building's heat gain use size of the overall balance of the building's energy needs. Currently, both legal instruments and computer tools take the heat gains use $100 \%$ or nearly for building heat needs to cover what in the real building is almost impossible to achieve because of heating system efficiency.
\end{abstract}

Keywords: heat gain utilization; building; heating; demand.

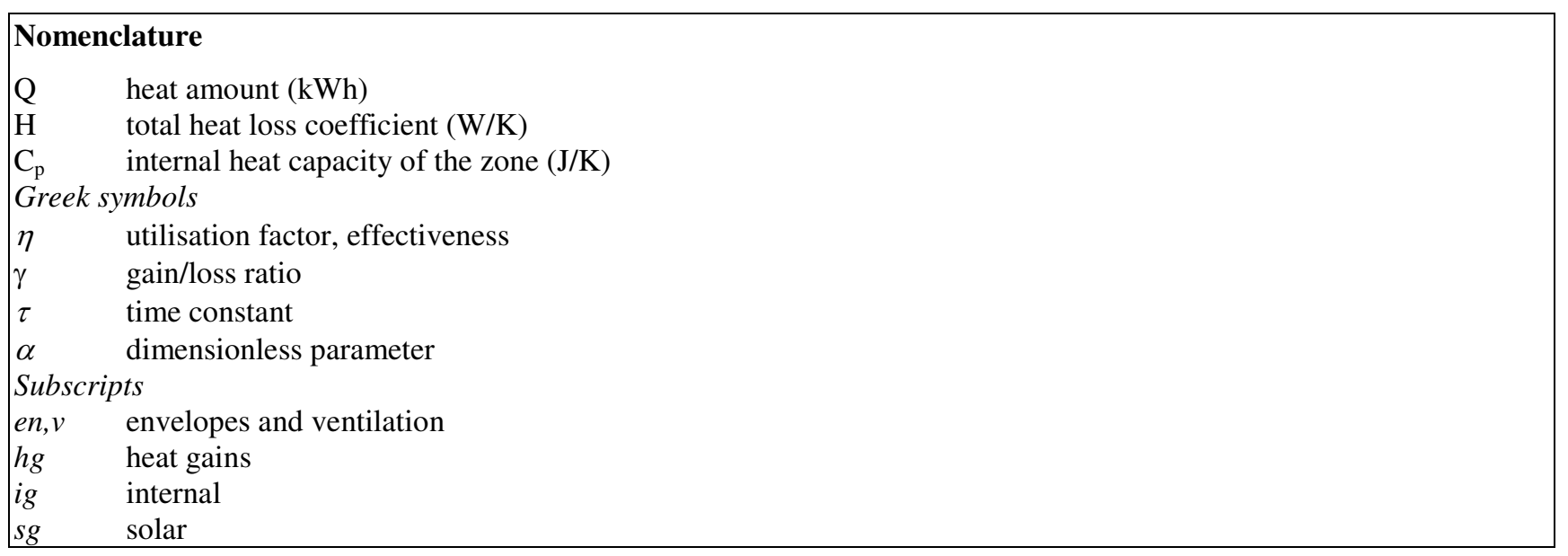

\section{Introduction}

Building energy performance became a key priority in EU - although big attention is paid for design of new low energy houses, the increase of efficiency in existing buildings is not less important. Here buildings energy consumption is an aspect that increases the attention due to ecological and economical reasons.

In order to meet new building performance standards, the calculations procedures should be carefully addressed.

The heat demand for heating of buildings on Lithuanian climate conditions usually is a major part of the overall building energy balance. Therefore, the exact and correct estimation of heat demand is very important both for the design of new, and especially for the analysis of existing, renovated buildings.

For building energy calculation, two approaches are widely used: simplified calculation and dynamic simulation [1]. Here LIDER [2], EnergyPlus [1], CONSOLIS ENERGY [3], TRNSYS [4] programs are used for dynamic simulation. The EnergyPlus and its interface (DesignBuilder) are probably the most popular and accurate dynamic simulation approaches.

Many authors compare theoretical and simplified methodologies for energy performance assessment. The methodology [5] introduces a simplified spreadsheet to evaluate energy demand, which is based on a seasonal heating calculation of heat

Corresponding author: Kęstutis Valančius. E-mail address: kestutis.valančius@vgtu.lt

http://dx.doi.org/10.3846/enviro.2014.285

(C) 2014 The Authors. Published by VGTU Press. This is an open-access article distributed under the terms of the Creative Commons Attribution License, which permits unrestricted use, distribution, and reproduction in any medium, provided the original author and source are credited. 
losses and usable heat gains for the building. The evaluation [6] focuses on the comparison of dynamic and static calculation results, in order to determine the correlation between the heat-balance ratio and the gain utilization factor. Stochastic comparison [1] determines that two different approaches (the simplified calculation method and EnergyPlus) require careful calibration for utilization factors in the simplified approach.

The increased and constantly increasing building energy efficiency requirements reduce the heat demand for heat losses compensation, so the heat gains part influence increases in a heat balance of a building. Here the operation control of heating systems is also essential, so it should be carefully analysed and assessed [7, 8, 9].

The common discussion about the heat loss and heat gains due to internal factors and solar radiation can be raised. But this article focuses specifically on the possibility of using or not the heat gains for building heating (not overheating!).

\section{Heat gains utilization factor}

For each building zone, the energy need for space heating for each calculation period (month or season) is calculated according to [10]:

$$
Q_{h}=Q_{e n, v}-\eta_{0} \cdot Q_{h g}
$$

The total heat loss demand $Q_{e n, v}$ is the sum of transmission $\left(Q_{e n}\right)$ and ventilation heat losses $\left(Q_{v}\right)$ and the total amount of heat gains $\left(Q_{h g}\right)$ consists from the internal heat gains (such as lighting and heat from appliances and persons) $\left(Q_{i g}\right)$ and from the solar heat gains $\left(Q_{s g}\right)$, which mainly consists from the solar radiation transmitted through windows.

Normative documents $[10,11]$ the heat gains part, which can be used for building heat losses compensation, usually defines as the heat utilisation factor $\left(\eta_{o}\right)$. The standard proposals [10-12,5] give for the gain utilisation factor for heating as a function of the gain/loss ratio:

$$
\eta_{0}=\frac{1-\gamma^{\alpha}}{1-\gamma^{\alpha+1}}
$$

where:

$$
\gamma=\frac{Q_{h g}}{Q_{e n, v}}
$$

The dimensionless parameter $\alpha$ is calculated, which is the same for heating (and for cooling):

$$
\alpha=\alpha_{0}+\frac{\tau}{\tau_{0}}
$$

For continuously heated buildings (more than 12 hours per day) such as residential buildings, hotels, hospitals, homes and penitentiary buildings $\alpha_{0}=1$ and $\tau_{0}=15 \mathrm{~h}$ (for monthly calculation).

The time constant for the heating mode $\tau$ characterises the internal thermal inertia of the heated space during the heating period. It is calculated from:

$$
\tau=\frac{C_{p}}{H \cdot 3600}
$$

where:

$H$ - total heat loss coefficient, W/K

$C_{p}$ - internal heat capacity of the zone, $\mathrm{J} / \mathrm{K}$

Coming from above equations the dimensionless parameter $\alpha$ can be expressed:

$$
\alpha=1+\frac{C_{p} / 3600}{15 \cdot H}=1+\frac{C_{p}}{5,4 \cdot 10^{4} \cdot H}
$$

The internal heat capacity of the building, $C_{p}$, is calculated by summing the heat capacities of all the building elements in direct thermal contact with the internal air of the zone under consideration:

$$
C_{p}=\sum_{i=1}^{n} A_{i} \cdot d_{i} \cdot \rho_{i} \cdot c_{i}
$$

where: $d_{i}$ - effective thickness of the structure; $A_{i}, \rho_{i}, c_{i},-$ respectively, area, density and specific heat capacity of the structure. 
The sum is done for all layers of each element, starting from the internal surface and stopping at the first insulating layer, the maximum thickness for determination of the utilisation factor is $10 \mathrm{~cm}$. or the middle of the building element; whichever comes first. According requirements $[10,13]$ building thermal inertia defines as:

Table 1. Building thermal inertia

\begin{tabular}{|c|c|c|}
\hline $\begin{array}{l}\text { Building thermal } \\
\text { mass }\end{array}$ & By structures mass and glazing area & $\begin{array}{l}\text { By internal heat capacity, } \\
C_{p}=(J / K)\end{array}$ \\
\hline Very light & $\begin{array}{l}\text { External envelopes mass }<50 \mathrm{~kg} / \mathrm{m}^{2} ; \\
\text { Glazing area }>50 \% \text { of total facades area. } \\
\text { Internal vertical envelopes mass }<50 \mathrm{~kg} / \mathrm{m}^{2} \text {. } \\
\text { Horizontal envelopes mass }<50 \mathrm{~kg} / \mathrm{m}^{2}\end{array}$ & $80000 \cdot A_{p}$ \\
\hline Light & $\begin{array}{l}\text { External envelopes mass }<50 \mathrm{~kg} / \mathrm{m}^{2} ; \\
\text { Glazing area }<50 \% \text { of total facades area. } \\
\text { Internal vertical envelopes mass }<50 \mathrm{~kg} / \mathrm{m}^{2} \text {. } \\
\text { Horizontal envelopes mass }>100 \mathrm{~kg} / \mathrm{m}^{2}\end{array}$ & $110000 \cdot A_{p}$ \\
\hline Medium & $\begin{array}{l}\text { External envelopes mass }<50 \mathrm{~kg} / \mathrm{m}^{2} ; \\
\text { Glazing area }<50 \% \text { of total facades area. } \\
\text { Internal vertical envelopes mass } 50-100 \mathrm{~kg} / \mathrm{m}^{2} \\
\text { Horizontal envelopes mass }>100 \mathrm{~kg} / \mathrm{m}^{2}\end{array}$ & $165000 \cdot A_{p}$ \\
\hline Massive & $\begin{array}{l}\text { External envelopes mass } 50-100 \mathrm{~kg} / \mathrm{m}^{2} \text {. } \\
\text { Internal vertical envelopes mass }<50 \mathrm{~kg} / \mathrm{m}^{2} \text {. } \\
\text { Horizontal envelopes mass }<50 \mathrm{~kg} / \mathrm{m}^{2}\end{array}$ & $260000 \cdot A_{p}$ \\
\hline Very massive & $\begin{array}{l}\text { External envelopes mass }>100 \mathrm{~kg} / \mathrm{m}^{2} . \\
\text { Internal vertical envelopes mass } 50-100 \mathrm{~kg} / \mathrm{m}^{2} \text {. } \\
\text { Horizontal envelopes mass }>150 \mathrm{~kg} / \mathrm{m}^{2}\end{array}$ & $370000 \cdot A_{p}$ \\
\hline
\end{tabular}

In summary on the basis on normative documents and other works [12, 5], the heat utilisation factor depends of the building envelopes' thermal inertia properties, heat losses and heat gains ratio what can be represented graphically:

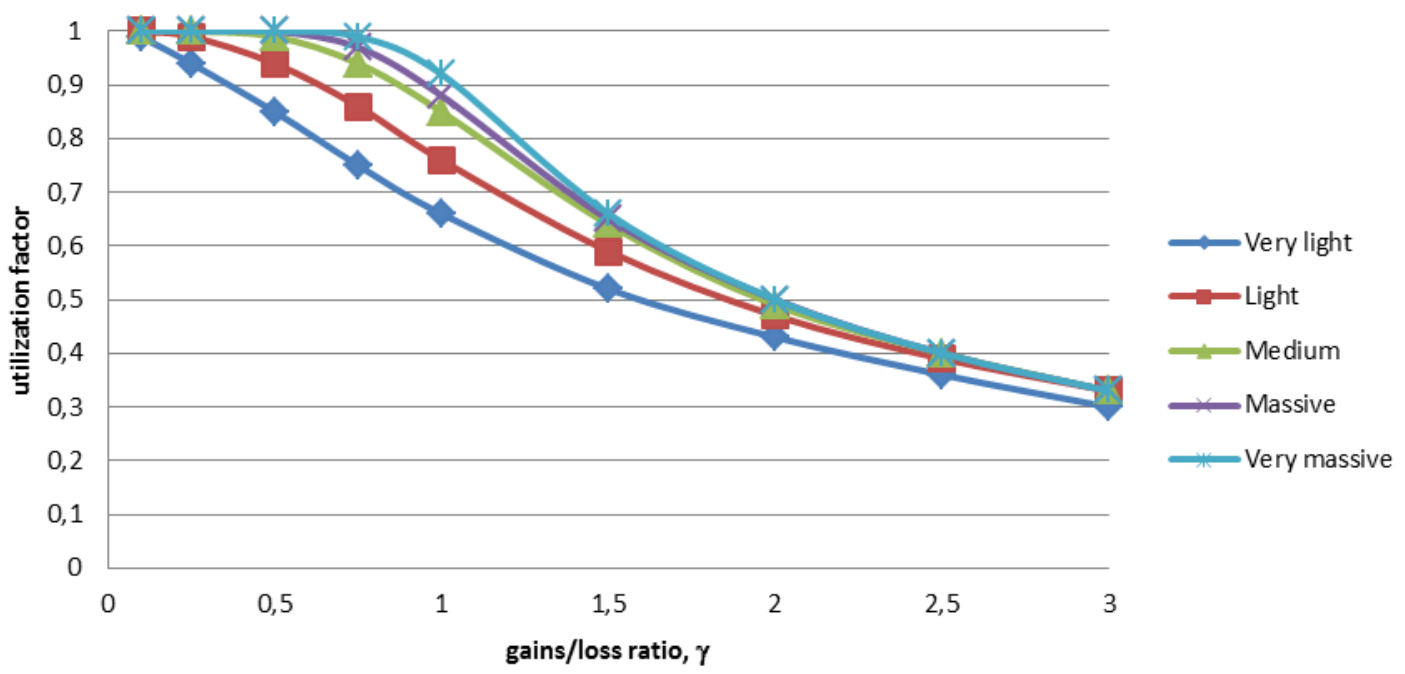

Fig. 1. Heat gain utilisation factor dependence on gain/loss ratio and building thermal inertia

Figure 1 shows the dependence of the heat gain utilisation factor on gain/loss ratio and building thermal inertia (comparing 5 types of them). Definitely the biggest difference can be seen between very massive and very light construction types. 


\section{Case study}

\subsection{Normative heat demand for the building heating}

First approximation in the case study is provided for a single zone residential building (Fig. 3) by using standard normative methodology [10]. The main characteristics of envelopes presented in Tables 2 and 3. Building climatic data - Kaunas, Lithuania, ventilation - natural (basically infiltration).

Some parameters for standard calculation is taken as near as possible according the simulation with EnergyPlus (section 2.2).

After the first consideration - the gain/loss ratio $\gamma=0.34$, so the results in Figure 2 are presented with heat gain utilization factor (according Fig. 1) $\eta_{o}=1\left(\mathrm{Q}_{\mathrm{h}}\right.$ (Massive)) and $\eta_{o}=0.9\left(\mathrm{Q}_{\mathrm{h}}\right.$ (Very light)). The area $\mathrm{Q}_{\mathrm{en}, \mathrm{v}}$ shows possible maximum heat demand when $\eta_{o}=0$.

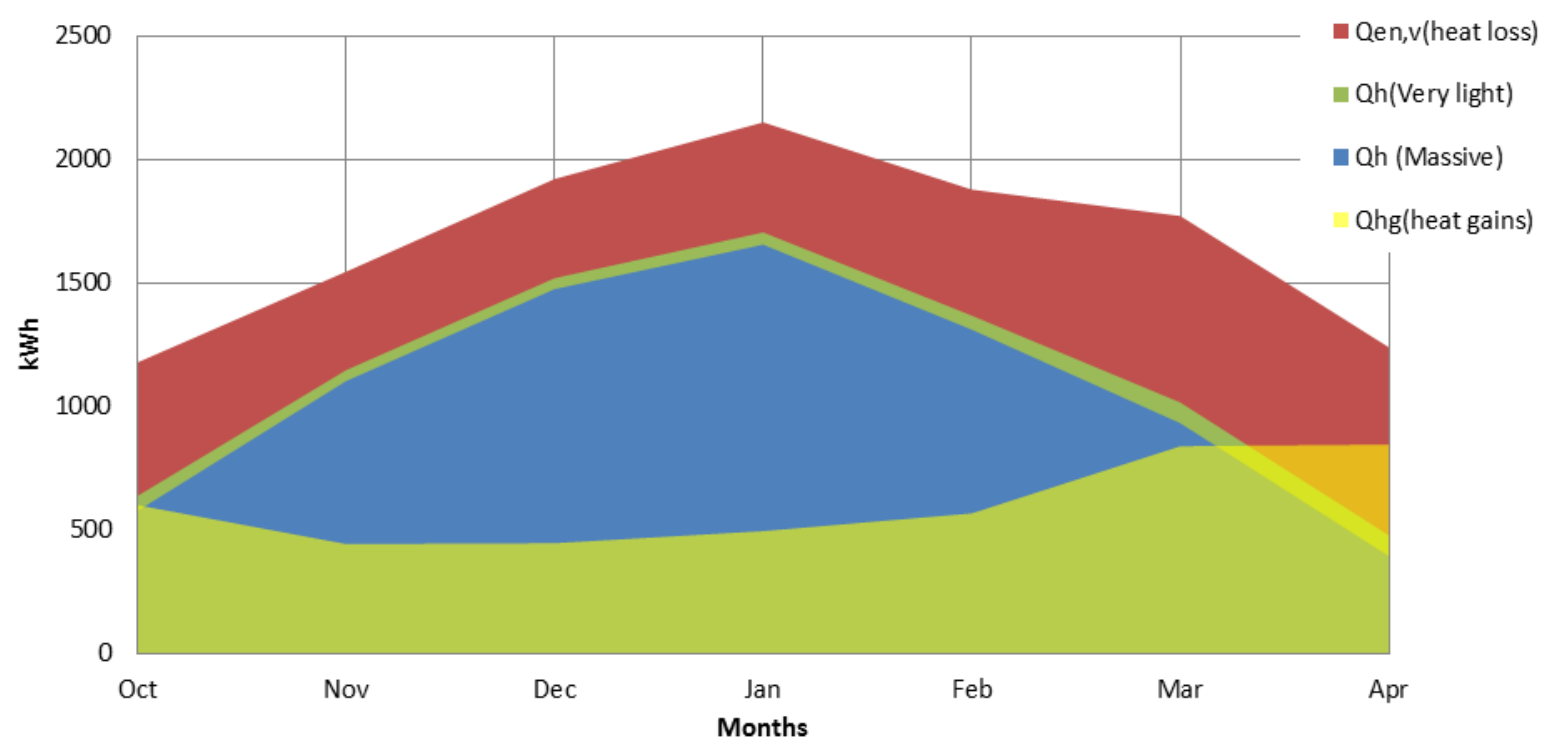

Fig. 2. Normative heat demand for the building heating

The final results show, what maximum annual heat demand, when heat gain utilization factor $\eta_{o}=0$, is equal to heat losses $\mathrm{Q}_{\mathrm{h}}=\mathrm{Q}_{\mathrm{en}, \mathrm{v}}$ according Eq 1 and is $11.7 \mathrm{MWh}$, the heat demand with $\eta_{o}=1 \mathrm{Q}_{\mathrm{h}}($ Massive $)=7.4 \mathrm{MWh}$ and $\eta_{o}=0.9 \mathrm{Q}$ $($ Very light $)=7.9 \mathrm{MWh}$.

\subsection{Simulation with DesignBuilder (EnergyPlus)}

DesignBuilder is a user-friendly software tool for architects, building services engineers, researchers, energy consultants and students for checking building energy, comfort, lighting and carbon performance. As DesignBuilder is developed by simplified building simulation, it allows to deliver the results quickly, easy and to have the parametric analysis in order to check the dependence.

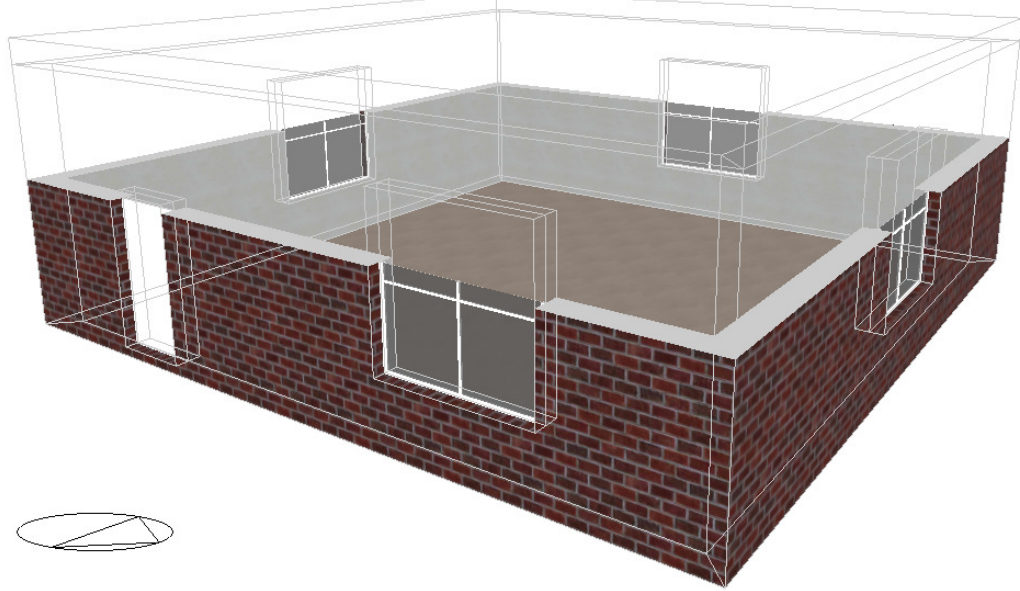

Fig. 3. Case study building model 
DesignBuilder is a comprehensive EnergyPlus interface, so it uses EnergyPlus location and weather data files. Building model can be either created in DesignBuilder or imported as 2D or 3D model. DesignBuilder also provides activity, construction, openings, lighting, HVAC templates, which simplifies the modelling procedures.

Table 2. Main characteristics of building opaque envelopes.

\begin{tabular}{|l|l|l|l|}
\hline & U-Factor $\left[\mathrm{W} / \mathrm{m}^{2}-\mathrm{K}\right]$ & Gross Area $\left[\mathrm{m}^{2}\right]$ & Cardinal Direction \\
\hline WALL_2 & 0.251 & 32.65 & E \\
\hline WALL_3 & 0.251 & 32.65 & N \\
\hline WALL_4 & 0.251 & 32.65 & W \\
\hline WALL_5 & 0.251 & 32.65 & S \\
\hline GROUNDFLOOR & 0.236 & 87.01 & \\
\hline ROOF & 0.149 & 87.01 & \\
\hline
\end{tabular}

Table 3. Main characteristics of building openings.

\begin{tabular}{|l|l|l|l|l|l|}
\hline & Area of Openings $\left[\mathrm{m}^{2}\right]$ & U-Factor $\left[\mathrm{W} / \mathrm{m}^{2}-\mathrm{K}\right]$ & SHGC & Shade Control & Cardinal Direction \\
\hline WALL_2_WIN & 4.00 & 1.500 & 0.472 & Yes & E \\
\hline WALL_3_WIN & 4.00 & 1.500 & 0.472 & Yes & N \\
\hline WALL_4_WIN & 4.00 & 1.500 & 0.472 & Yes & W \\
\hline WALL_5_WIN & 4.00 & 1.500 & 0.472 & Yes & S \\
\hline WALL_2_DOOR & 2.00 & 1.500 & - & - & E \\
\hline
\end{tabular}

Building monthly simulation results in Figure 4 shows general similarity with normative calculation (Fig. 2). The annual heat demand ("sensible heating") in this case is 7.2 MWh. The aim of the simulation is not to equalize the results, but to find out the tendencies of the results reliability [6].

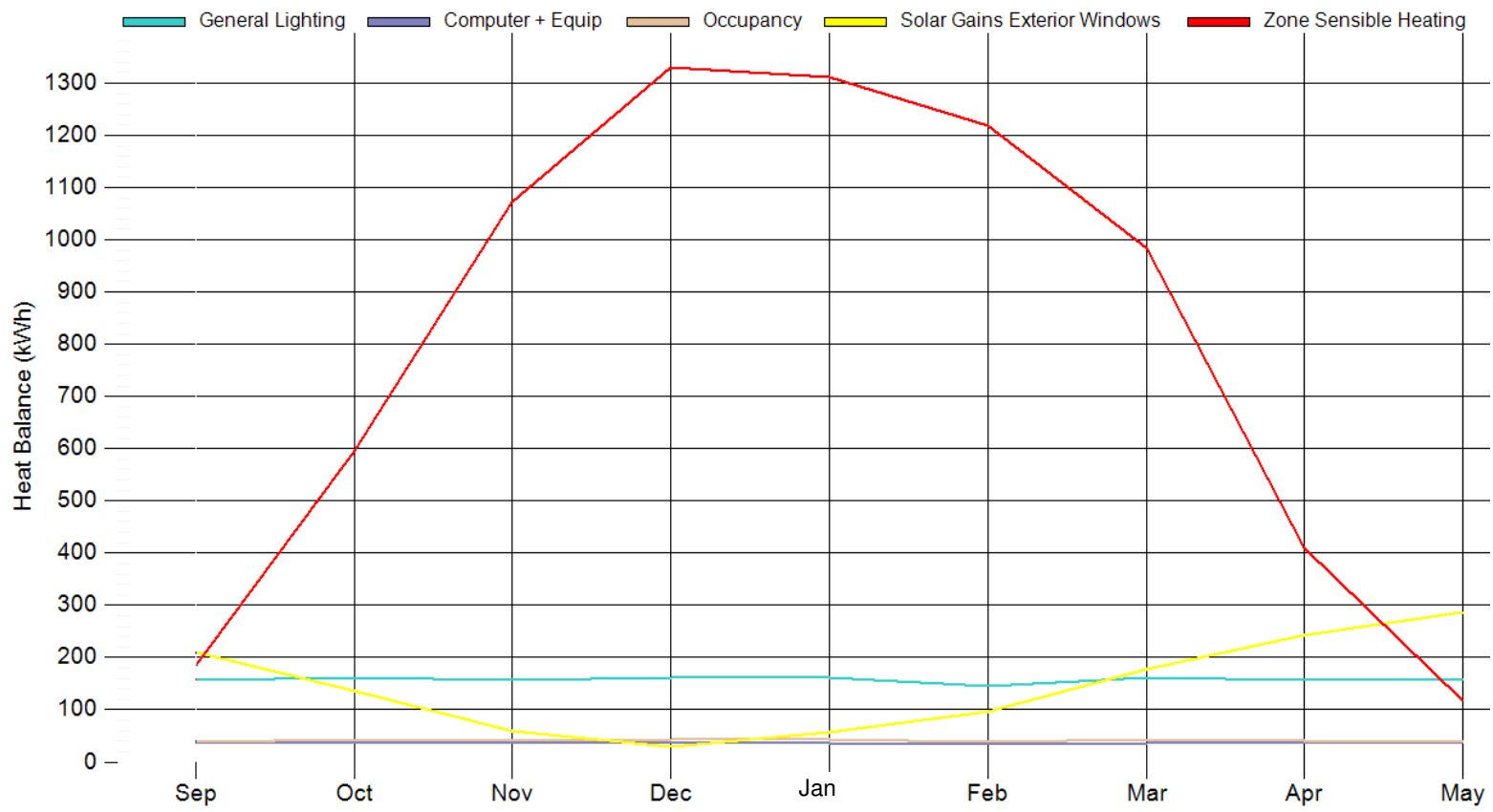

Fig. 4. Monthly building (zone) heat balance 
The more detail daily simulation results are presented in Figure 5. Despite the fact of external and internal thermal factors and outdoor temperature dispersion - indoor air temperature remains constant according set point $+22{ }^{\circ} \mathrm{C}$. This shows that in this case, the heating system is working "perfectly" in response to external stimuli, and maximum use the heat gains, that can equate $\eta_{o}=1$ and, therefore, noticeable similarity to the results of normative calculation (section 2.1) result $\mathrm{Q}_{\mathrm{h}}($ Massive $)=7,4 \mathrm{MWh}$.

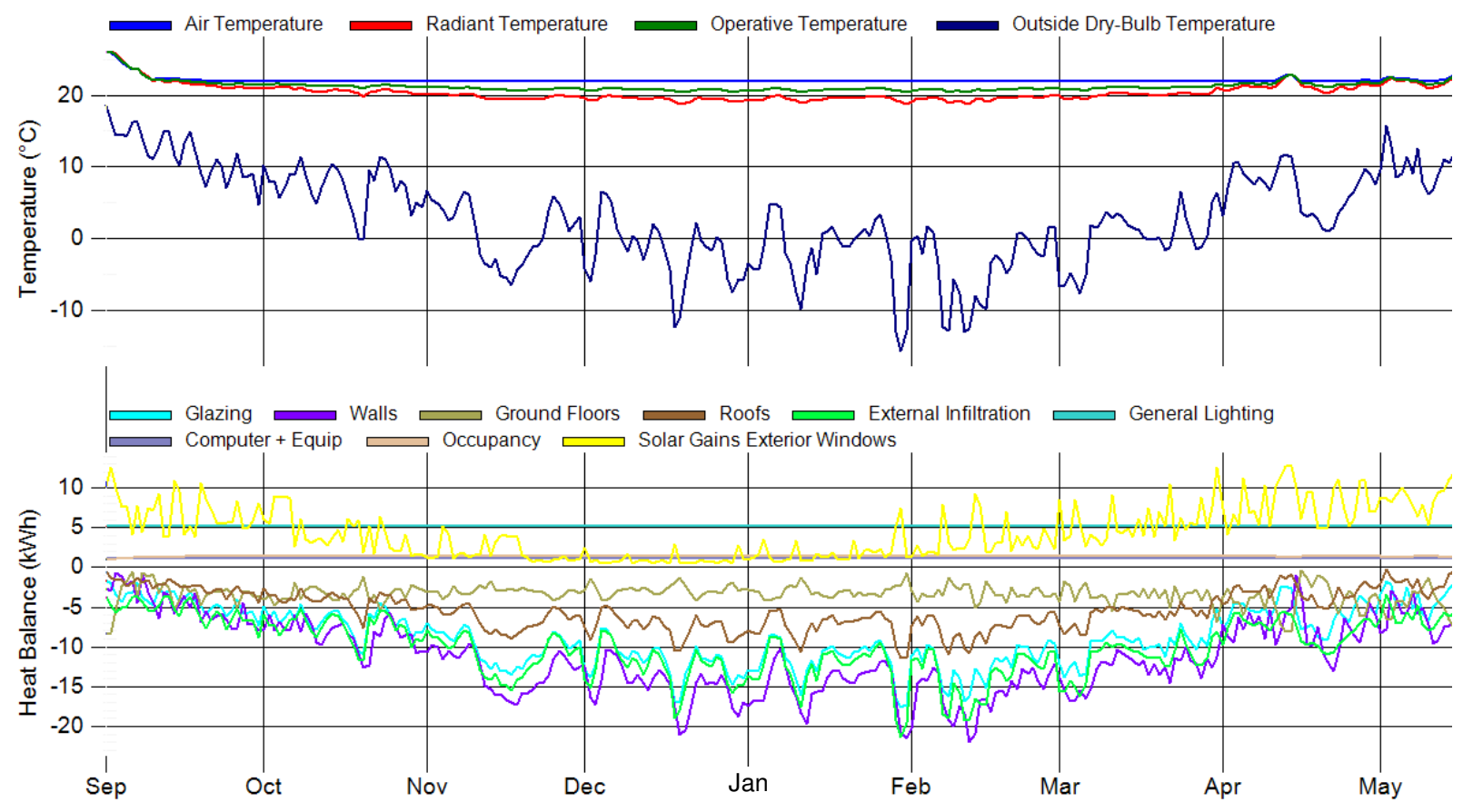

Fig. 5. Daily building (zone) heat balance and temperature distribution

\section{Efficiency of the system}

The efficiency of a heating installation can be defined in different ways. The overall efficiency at system level neglects the interactions with the building. The works $[1,4,14]$ defines the overall efficiency with respect to the building as model boundary and it can be described as the product of heat production and system efficiency. The former covers the production of heat by the boiler; the latter incorporates emission and distribution of heat. These efficiencies obviously depend on the technologies and control schemes used, but also on the building itself.

As stated, the system efficiency can be calculated as the ratio of the overall to the production efficiency or $\eta_{\text {overall }}=$ $\eta_{\text {system }} \cdot \eta_{\text {production }}$. And the survey [4] finds out that $\eta_{\text {overall }}$, depending on different modern control of heat source and heat emitters (radiators, convectors), varies between $64 \%$ and $84 \%$. Even seasonal efficiency range is between $\sim 10 \%$ and $90 \%$.

Figure 6 represents normative heat demand additional to heat utilization factor using overall system efficiency impact.

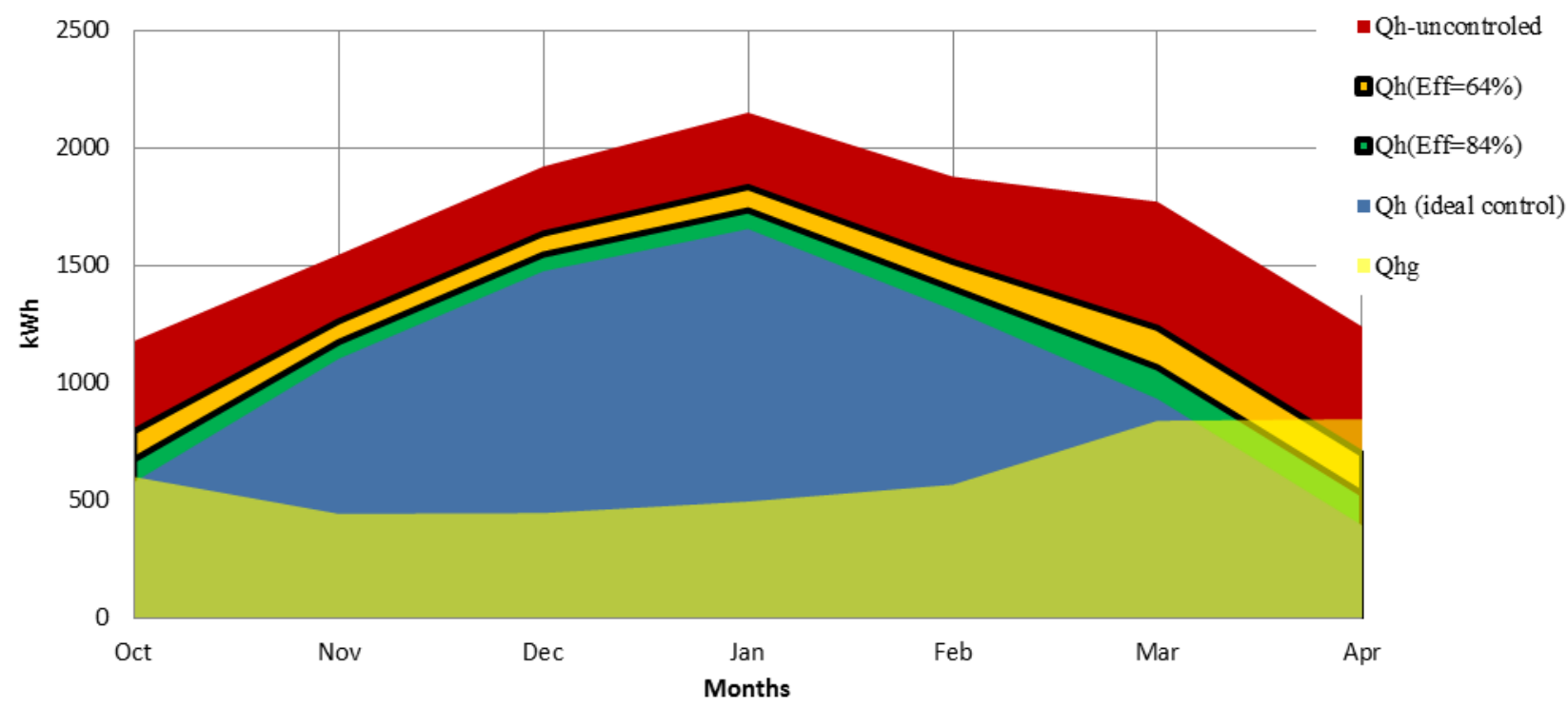

Fig. 6. Normative heat demand for the building heating including system efficiency 
In this case area between solid curves shows heat demand with heat utilization factor $=1$ and system efficiency between $64 \%$ and $84 \%$. The $\mathrm{Q}_{\mathrm{h}}$ (ideal control) area is the same as in Figure $2 \mathrm{Q}_{\mathrm{h}}$ (Massive) $=7.4 \mathrm{MWh}\left(\eta_{o}=1\right.$ or/and $\left.\eta_{\text {eff }}=100 \%\right)$ and can be assumed as ideal case with system efficiency $100 \%$ and constitutes $64 \%$ of maximum possible heat demand $\mathrm{Q}_{\mathrm{h} \text {,uncontrolled }}\left(\mathrm{Q}_{\mathrm{en}, \mathrm{v}}\right)$. Respectively $\mathrm{Q}_{\mathrm{h}, \mathrm{eff}=64 \%}\left(\right.$ with $\eta_{\text {eff }}=64 \%$ ) is $9 \mathrm{MWh}$ and constitutes $77 \%$ of $\mathrm{Q}_{\mathrm{en}, \mathrm{v}}$, and $\mathrm{Q}_{\mathrm{h}, \mathrm{eff}=84 \%}$ (with $\eta_{\text {eff }}=$ $84 \%$ ) is $8,1 \mathrm{MWh}$ and constitutes $70 \%$ of $\mathrm{Q}_{\mathrm{en}, \mathrm{v}}$.

\section{Conclusions}

Part of heat gains which is used for heating to maintain the constant set temperature is defined as heat utilization factor for determination of the building heat demand according to normative documents.

This factor is directly dependent on the heat loss, heat gains size and thermal inertia properties, but underestimates the level of system control (central thermostat, thermostats on heat emitters, heat source control). Therefore, usually the heat demand of the building is set for the ideal case and is less than the actual one.

It is recommended for the calculation of heat demand, heat utilization factor to take as the ability to use the maximum heat gains or $\mathrm{Q}_{\mathrm{h} . \mathrm{min}}$. The amount of heat loss compensation $\mathrm{Q}_{\mathrm{en}, \mathrm{v}}$ defined as $\mathrm{Q}_{\mathrm{h} \text {.max }}$ or as a heat demand, when the system is controlled only by the outside temperature, but there is no space (zone) heating control devices. Then the actual heat demand, evaluating the system efficiency, ranges between $\mathrm{Q}_{\mathrm{h} . \min }$ and $\mathrm{Q}_{\mathrm{h} . \max }$, and according this study the overall system efficiency (especially for residential buildings) can be assumed between $64 \%$ and $84 \%$.

\section{References}

[1] Kim, Y.-J.; Yoon, S.-H.; Park, C.-S. 2013. Stochastic comparison between simplified energy calculation and dynamic simulation, Energy and Buildings 64: 332-342. http://dx.doi.org/10.1016/j.enbuild.2013.05.026

[2] Pardo, Á. R.; José, F.; La, S. D. E.; Soria, C. S.; Luis, J. 2005. Building envelope optimisation, Journées Internationales de Thermique 12: $415-418$.

[3] Kalema, T.; Pylsy, P. 2005. Accuracy of the Calculation of Heating and Cooling Energy Needs in Nordic Conditions.

[4] Peeters, L.; Van der Veken, J.; Hens, H.; Helsen, L.; D'haeseleer, W. 2008. Control of heating systems in residential buildings: Current practice, Energy and Buildings 40(8): 1446-1455. http://dx.doi.org/10.1016/j.enbuild.2008.02.016

[5] Carlos, J. S.; Nepomuceno, M. C. S. 2012. A simple methodology to predict heating load at an early design stage of dwellings, Energy and Buildings 55: 198-207. http://dx.doi.org/10.1016/j.enbuild.2012.06.033

[6] Wauman, B.; Breesch, H.; Saelens, D. 2013. Evaluation of the accuracy of the implementation of dynamic effects in the quasi steady-state calculation method for school buildings, Energy and Buildings 65: 173-184. http://dx.doi.org/10.1016/j.enbuild.2013.05.046

[7] Maheshwari, G. P.; Al-taqi, H.; Al-murad, R.; Suri, R. K. 2001. Programmable thermostat for energy saving, Energy and Buildings 33: 667-672. http://dx.doi.org/10.1016/S0378-7788(00)00132-8

[8] Wei, S.; Jones, R.; de Wilde, P. 2014. Driving factors for occupant-controlled space heating in residential buildings, Energy and Buildings 70: 36-44. http://dx.doi.org/10.1016/j.enbuild.2013.11.001

[9] Ruivo, C. R.; Ferreira, P. M.; Vaz, D. C. 2013. Prediction of thermal load temperature difference values for the external envelope of rooms with setback and setup thermostats, Applied Thermal Engineering 51(1-2): 980-987. http://dx.doi.org/10.1016/j.applthermaleng.2012.11.005

[10] STR 2.09.04:2008. Pastato šildymo sistemos galia. Šilumos poreikis šildymui. [Lithuanian building technical regulation].

[11] LST EN ISO 13790:2008. Thermal performance of buildings. Calculation of energy use for space heating. [Lithuanian Standards Board].

[12] Kalema, T.; Jóhannesson, G.; Pylsy, P.; Hagengran, P. 2008. Accuracy of Energy Analysis of Buildings: A Comparison of a Monthly Energy Balance Method and Simulation Methods in Calculating the Energy Consumption and the Effect of Thermal Mass, Journal of Building Physics 32(2): 101130. http://dx.doi.org/10.1177/1744259108093920

[13] STR 2.01.09:2012. Pastatu energinis naudingumas. Energinio naudingumo sertifikavimas. [Lithuanian building technical regulation].

[14] Moon, J. W.; Han. S.-H. 2011. Thermostat strategies impact on energy consumption in residential buildings, Energy and Buildings 43: $338-346$. http://dx.doi.org/10.1016/j.enbuild.2010.09.024 